316.7 Београд
https://doi.org/10.18485/msc.2018.47.2.ch9

Соња Д. ПЕТРОВИЋ

Универзитет у Београду

Филолошки факултет
Оригинални научни рад

Примљен: 22. 4. 2018.

Прихваћен: 23. 4. 2018.

\title{
СВАКОДНЕВНИ ЖИВОТ НА УЛИЦАМА БЕОГРАДА: ОБЛИКОВАҢЕ ЛИЧНИХ СЕЋАЬА У УСМЕНОЈ ИСТОРИЈИ И АУТОБИОГРАФСКОЈ ПРОЗИ
}

\begin{abstract}
На стецишту наратолошке, симболичко-географске, психолошке и социолошке анализе простора и идентитета, на примерима одабраних усмених историја и аутобиографија разматрају се поступци приказивања и обликовања личних сећања на свакодневни живот у Београду око 1930-1950. Чиниоци јавних градских простора, као што су улице и тргови, схваћени су као простори учења различитости и другости који постају средство идентификације у наративном уобличавању сећања. У средишту пажње су лична сећања на београдске уличне продавце и исказивање идентитета и духа града у приповедању о њима. Фрагментарна и неуобличена сећања у процесу приповедања добијају структуру и стабилност, али се и мењају, прилагођавају и реконструишу. Оживљавање духа града у сећањима представља динамичан идентитетски процес, подржан и омогућен друштвеним структурама, ритуалима и праксама у свакодневици. Поједини аспекти идентитета исказују се кроз испољавање актера у комуникацији с другима, који га признају и потврђују, или оспоравају.

Кључне речи: аутобиографска сећања, Београд 1930-1950, усмена историја, аутобиографија, свакодневни живот, приповедање, простор, наративни идентитет, улични продавци.
\end{abstract}

\section{Оквири истраживања: свакодневица, сећање/памћење и приповедање}

Вербализација сећања на свакодневни живот у граду последњих деценија изазива велико научно интересовање везујући се како за културу памћења, тако и за тзв. просторни заокрет у хуманистичким и друштвеним наукама. Свакодневни живот у садржинском смислу односи се на активности обичног, анонимног човека које се понављају из дана у дан и служе одржању егзистенције, при чему су у средишту пажње сфере рада, породице и доко-

*sonja.petrovic@fil.bg.ac.rs 
лице. Свакодневицу, приповедање и памћење повезао је француски филозоф Мишел де Серто у својој студији о свакодневном животу (1988). Проучавање свакодневице посветио је „обичном човеку, свеприсутном лику, анонимном јунаку” који је „нови херој” данашњег времена, а као метафору за свакодневне праксе узео је говорни чин, уклопљен у контекст у ком се одвија, односно хетерогене „гласове Другог” (Спасић 2004: 222; Серто 1988: 103; Хајмор 2006: 88). Свакодневна конверзација, као препричавање догађаја и рециклирања прича, представља за Сертоа један од облика „секундарне производње” и уједно поетичке (стваралачке) активности, какве су и читање, кување, становање, свакодневни ритуали, употреба градског простора кретањем, путовање (Спасић 2004: 218-219). Свакодневни разговори, као и говор у целини, јесу вид стварања друштвене стварности путем „мајсторисања” (бриколажа), и у односу на владајућу културну економију иду заобилазним путевима субверзије, па „свакодневни живот себе изумева кроз безбројне начине криволова на туђем имању" (Спасић 2004: 218). Памћење је такође скопчано са свакодневицом - оно је ,једна врста антимузеја" и не може се прецизно локализовати у простору. Фрагменти сећања откривају се у легендама, „прошлост дрема у предметима и речима", у свакодневним праксама, а успомена је као „краљевић из бајке који се задржава тек да би пробудио успаване лепотице наших прича без речи”. Серто пише да су „места у којима људи живе као присуства разних одсутности”, а „оно што се може видети означава оно чега више нема на том месту: 'Видите, овде је било...', али то се више не може ту видети" (Серто 1988: 108).

Поред тога што је памћење везано за свакодневне праксе, оно има велики значај за разумевање сопства и друштва, укључујући ту и питања стварања и преношења усмене традиције и приповедног обликовања сећања у многобројним усменим, књижевним и документарним жанровима (животне приче, аутобиографије, мемоари, романи, путописи, писма и др.). Иако су варљива и непоуздана, сећања чине један од темеља људског идентитета и омогућавају изградњу сопства и комуникацију с Другим, али стварају и различитост од Другог јер, како пише Зебалд, „само на хоризонту претходних стања и околности неидентитета, постаје видљиво оно што је различито, ново" (2010: 3). Према Алаиди Асман (2011: 22-25), сећања су перспективистичка (сваки појединац има властиту позицију опажања); затим, умрежена са сећањима других људи (то им даје кохерентност, веродостојност и важну улогу у повезивању и образовању заједнице); и најзад, сећања су фрагментарна, ограничена и неуобличена и тек у приповедању добијају структуру и стабилност, али се уједно мењају, прилагођавају и реконструишу. Отуд од понављања сећања у конверзацији зависи и мера њихове очуваности - о чему сведоче разни примери усмене традиције. Како су грешке у памћењу пре правило него изузетак, непостојаност сећања је саставни део физиолошких и неуролошких процеса у мозгу и уједно последица промена саме личности, животних околности, промене структура релеванције и мерила вредновања. Ако се има у виду чињеница да с нестанком носилаца сећања нестају и сама сећања, и да се простор града као предмет индивидуалног и друштвеног памћења често бесповратно мења, њихово проучавање има огроман значај. 


\section{Град, идентитет и различитост}

Лична сећања на град и на свакодневне праксе указују се као сложен феномен у исказивању идентитета. Живећи у градовима, људи својим активностима утичу на простор и дају му одређена симболичка значења. Наслојавањем значења градови постају „урбани палимпсести”, при чему могу и да „отелотворе, материјализују и репрезентују колективно памћење и да га сублимирају у простору и времену" (Радовић 2013: 11). За онога ко износи успомене на живот у граду, чиниоци простора учествују на више начина, нпр. као материјална референца, ментална топографија, облици дискурзивног симболизма и др. У самом приповедању, градска места могу да постану битне тачке ослонца композиције, чворишта радње или да се претворе у места рефлексије тако што активирају низ асоцијација. Чиниоци простора, оживљени одређеним праксама или имагинацијом као симболичка места (Кресвел 2004: 33-39; Спасић, Бацковић 2017: 25-26) и културни конструкти, постају средство идентификације у наративном уобличавању сећања. Градске четврти, зграде, споменици, паркови и друга места постају у приповедању тачке око којих се организују догађаји, а посебан значај добијају кад им се придају лична, емотивна, симболичка и имагинативна значења. Ова значењска слојевитост остаје присутна и онда кад места о којима се приповеда више нису физички присутна или су присутна у измењеном виду и с другачијом наменом. Кад се приповедање о личним сећањима и преживљавањима веже за одређена градска места, настају особена сведочења која могу да осветле дух или идентитет града, његову јединственост и идејну страну. ${ }^{1}$ Како се идентитет у многим аспектима исказује релационо, у друштвеном саобраћању, однос између града и његових становника је међусобно условљен јер градови „одражавају и обликују вредности и гледишта својих становника на различите начине” (Бел, Де Шалит 2011: 2). Штавише, Спасић и Бацковић сматрају да су идентитет и слика града само две стране исте појаве: „Јер, шта и како од града перципирају други, извана му приступајући, улази у саму конструкцију идентитета, кроз стални дијалог са унутрашњим доживљајем - било кроз надопуњавање и слагање, или кроз судар и активно оповргавање, или пак резигнирану помиреност упркос неслагању" (2017: 17). Следећи ова размишљања, може се рећи да је оживљавање духа града у сећањима динамичан идентитетски процес, подржан и омогућен управо друштвеним структурама, ритуалима и праксама у свакодневици (како су то показали Албвакс и Конертон). Градски јавни простори су места на којима се одигравају живи друштвени сусрети и размене, и утолико су то простори учења различитости, другости (Шаринић и Чалдаровић 2015: 199). Уједно, град је место изразитих социјалних противречности на разним плановима, а заједнички живот у граду „одувек је представљао највећи могући степен међусобног усклађивања

\footnotetext{
${ }^{1}$ Социолози Ивана Спасић и Вера Бацковић идентитет града описују као „скуп јединствених особина и обележја који обезбеђује трајну препознатљивост једном граду у поређењу с другим градовима, по којима се од њих разликује и признаје као посебан” (2017: 16).
} 
друштвених различитости” (Пушић 2015: 362). Дистинкција је, такође, кључ разумевања идентитета - „властити градски идентитет стиче кроз усвајање разлике и различитог јер историјски градови јесу социопросторне творевине 'искуства разлике"' (Вујовић 2014: 146).

\section{Из сећања на свакодневни живот Београда: улични продавци као Други}

Полазећи од поменутих идеја о повезаности приповедања, памћења и свакодневице, указаћемо на поједине начине представљања призора из свакодневног живота у Београду у усменим историјама и аутобиографијама. Задржаћемо се на поступцима приповедног оживљавања градског простора и неким аспектима перцепције различитости имајући у виду просторне и контекстуалне оквире.

У деценијама пре и непосредно после Другог светског рата Београд је у географском и демографском смислу био релативно скромних димензија, али независно од тога му је приписиван препознатљив и јединствен градски дух који се исказивао, између осталог, у мултикултуралности града. Демографске анализе становништва у Београду у периоду од 1918. до 1941. године илуструју велику етничку разноврсност (Радовановић 1974: 158), а она је била присутна и у ранијим раздобљима (Поповић 1964: 303-306, 347-350). Пораст броја становника, миграције и етничка шароликост ишли су упоредо с убрзаном изградњом Београда и његовим развојем на урбанистичком, економском и културном плану, па су ти глобални процеси оставили трага у личним сећањима како на поједина места у граду, тако и на свакодневни живот.

Сећања на градску свакодневицу у наративном смислу у вези су са перцепцијом и дочаравањем простора, људи и разних друштвених пракси. Приповедне технике приказивања простора „дају тело и облик визуализацијама које урањају читаоца у приповедни свет", а најчешће се користе описи, као „главне дискурзивне стратегије” (Рајан 2009: 426). Увођење дескрипције обуставља радњу и дозвољава да се простор представи с више појединости, чиме се пажња читалаца или слушалаца усмерава на просторни оквир. Унутар описа могу да буду укључени актери који се крећу или делају у неком простору, затим различите перцептивне позиције ликова или наратора, њихови идејни ставови, оцене, емоције. Нинингова разграната систематизација описа показује њихову функционалност и везу с другим приповедним чиниоцима (2007). Теоретичари који су разматрали однос простора и приповедања указали су и на хибридне жанрове где су помешане дескрипција и нарација (нпр. планови зграда или градских четврти приказани су посредством описа градње), и на случајеве где се описи везују за последице збивања које се одражавају на промену простора (Рајан 2009: 426). Описи се покрећу коришћењем технике зумирања - приближавања и удаљавања фокуса, чиме се помера просторна пози- 
ција посматрача у односу на приповедане догађаје: чиниоци описа се стављају у предњи план или у позадину (Херман 2002: 274).

Један од карактеристичних призора у описима београдске свакодневице приказује кретање људи на улицама који обављају неки посао: чистачи улица, млекаџије, сакаџије, продавци новина, сладоледа, печеног кукуруза, пецива, ушећереног воћа и кокица, лимунаде, крахера, бозе, салепа, кикирикија, семенки; или ледаџије, ћумурџије, разни превозници на коњским и воловским колима, затим чистачи ципела, путујући мајстори, свирачи, просјаци, сезонски радници и многи други. Својим присуством на улицама ови актери давали су специфичну атмосферу и чинили део свакодневице, доприносећи креирању духа града. Чести сусрети с овим незаобилазним Другима, који су безмало прерасли у општа места приповедања, срећу се у великом броју усмених историја и аутобиографија у виду личне успомене или као уопштен опис из живота града. Слике уличних продаваца и града могу бити приказане панорамски представљањем карактеристика одређеног места (улице, трга, пијаце, четврти), тако да се у широком плану обухвати структура простора, или се опис динамизује увођењем релативно независних приповедних секвенци у којима се неки од поменутих актера крећу градским улицама увек истом путањом и својим делатностима испуњавају свакодневицу. Почетак дана на београдским улицама Нада Дорошки описује овако (1997: 84-85):

У ране јутарње сате клопарање трамваја који су излазили из депоа у Александровој улици (данас Булевар револуције) било је први знак да се Београд буди из ноћног сна. [...] После трамваја на београдске улице ступале су млекаџије. Долазиле су из околних села у лаким чезама натовареним лименим кантама и заустављале се пред кућама својих муштерија. Забрађене снаше у народним ношњама и сељаци са шајкачама на глави пртили су тешке канте од спрата до спрата. Миришљаво, густо млеко, тек помузено, претакало се из канти у шерпе и лонце које су, још буновне домаћице или служавке, протурале кроз одшкринута врата. Свака породица имала је обично свог сталног млекаџију, а плаћало се месечно - кад се прими плата.

Овај извод из ширег описа јутра у Београду, визуелно богат и динамичан, садржи призоре из свакодневице и културноисторијске податке. ${ }^{2}$ Идентитет становника града изграђује се кроз животне стилове и диференцира у односу према Другом - сељацима и сељанкама одевеним у народне ношње и шајкаче које имају традиционално и национално обележје. Разликовање руралног и урбаног сугерисано је и са становишта простора, где се исцртавају јасне хоризонталне и вертикалне границе према Другом: сељаци прте тешке канте уз спратове, примопредаја млека врши се на прагу, свој простор се контролише у односу на посетиоце. У овом примеру, као и неколико других, реч је о наративизовању дечјих сећања која су побуђена посредством звучних и олфакторних утисака (звуци јутра, мирис млека, његова текстура). Неуролошка истраживања показују да су сећања везана за чула мириса и укуса старија и постојанија од сећања скопчаних с вербалним и визуелним информацијама

\footnotetext{
${ }^{2}$ Снабдевање Београђана млеком на описани начин, сипањем из канте у шерпу, престало је око 1952-1953. године, а потом су шерпе замењене стакленим флашама које су остављане испред врата.
} 
(Виландер, Ларсон 2006), па не изненађује што се управо њима започиње казивање о свакодневици.

Два сећања на млекаџије: аспекти приповедања

Другачији поступак обликовања сећања на свакодневне јутарње ритуале у Београду налазимо у казивању Михаила Лакчевића (2011):

Да ти почнем негде од почетка, од јутра. Значи, мир, тишина, шта чујеш у Београду негде око пет, шест сати? Така, така, така, коњске копите иду. Шта је сад? Млекаџије носе млеко. Није онда било у радњама, осим тога рано је било, знаш, а школе почињу у осам сати, радње почињу од осам, радно време од осам. Значи, до осам сати треба маме да спреме млеко деци да оду у школу да имају млеко, а радње не раде, а мислим да у радњама и није било млека него су носиле млекаџије из околних села. А шта су села онда била у Београду? Карабурма била село, рецимо, Жарково село било. То су све биле наше млекаџије. Значи та околина Београда, то је сад у ствари Београд, знаш. [...] И шта онда буде? Иду млекаџије рано сабајле и наравно свашта чују. Онај од онога, онај од онога. И постојао неки виц, знаш. Пошто они рано иду и свашта чују док дођу до тебе, до куће, и онда је посто виц, кад нешто причаш: „Па откуд знаш то? Ди си чуо? Па није то истина?” - „Па како није истина, причо ми млекаџија”. - „Причо ми млекаџија”. Зашто? Зато што рано покупи све новости од јутрос, знаш. И шта онда, сад тај млекаџија наш дође рано пред кућу, уђе у моју петоспратницу, код Политике сам становао, и свака кућа која је имала наравно потребу за млеком, изнесе лонче напоље испред куће. И млекар већ зна, Лакчевић - два литра. Нас шесторо, знаш. [...] И он сипа то, имао је две мерице, кантицу узме. Остави он кола његова, знаш каква су била кола? Коњ, седиште за возача, позади платформица, ту четири канте од, па рецимо, од десет литара. Једну канту граби, две мерице и иде код свакога и само каже ко је, сипа у ону шерпицу два литра и поклопи, није уопште било никаквих проблема. И он остави кола напоље, неко да украде - нема шансе.

Евоцирање сећања преко звучних утисака може да има и просторну компоненту - разлегањем топота млекаџијских коња маркирају се симболичне границе географског и културног простора насељеног житељима града. Док су у тексту Н. Дорошки истакнуте социјалне и културне разлике, овде млекари, мада долазе с периферије, нису идеолошки супротстављени градским становницима, него се описују међусобна присност и сарадња - „тај млекаџија наш” тачно познаје потребе станара и свој посао обавља брзо, ненаметљиво и делотворно.

Начин на који је Лакчевић презентовао своја сећања у великој мери је одређен контекстом интервјуа и односом између саговорника. Оринг је приметио да се често узима здраво за готово да саговорник у интервјуу осмишљава казивање као 'своју причу' тј. као причу 'за себе' (о свом идентитету), али заправо он се прилагођава истраживачу који својим питањима и коментарима усмерава одговоре (1988: 183). Наведени одломак део је разговора вођеног између деде и унуке за потребе студенске теренске збирке, па се запажа да Лакчевић, имајући у виду знање и животно искуство своје саговорнице, објашњава не само свакодневну рутину, него и просторне односе и удаљености између центра и периферије 'некад' (време приповедачевог детињства које се евоцира) и 'сад' (време казивања) - данашњи делови града Карабурма и 
Жарково не тако давно били су удаљена села. Затим, он наглашава осећање сигурности и међусобног поверења (није било страха од крађе), и финим појединостима осветљава значај млекаџија за породице, чиме их чини неодвојивим делом градског живота. Ови подаци, по себи културноисторијски, поткрепљују веродостојност и документарност казивања, док с друге стране непретенциозна дијалошка стилизација и блага педагошка нота дају причи известан идеализован, носталгичан прелив. Градска свакодневица оживљена је на сликовит и шаљив начин приписивањем млекаџијама улоге посредника у преношењу гласина, што им заправо доноси локални углед и истиче њихову социјалну покретљивост.

У аутобиографским сећањима налазимо проницљиве карактеризације људи који су чинили београдску уличну свакодневицу. Обухваћене су разнолике приповедне технике, нпр. језгровите дескрипције збивања и поступака актера, ауторски коментари, психолошки портрети у којима се опис свакодневне праксе комбинује с описом и критиком менталитета, а слика Другог се у исто време конкретизује и прераста у опис специфичног друштвеног типа. Веома успео опис фокусиран на карактер илуструје случај Милорада млекаџије - окретног, прилагодљивог, похлепног, али и субверзивног типа 'малог привредника', кога духовито представља Милош Крстић у сећањима на детињство проведено на Врачару:

[...] Свакодневно се у цик зоре појављивао виспрени Милорад из Пиносаве са млеком, а повремено и доцкан увече са телетином заклањајући се иза Лењинове догме „никад није доцкан”. Заправо ово је био тенденционално искоришћен само први део научне истине која у целости гласи „никад није доцкан да се стигне доцкан” (Марфијев закон). Телетину је Милорад препродавао као илегалац ноћу. Једном када је ухапшен и бачен у тамницу појавио се и повећи наслов у „Политици” (већина је куповала лист због Паје Патка) „Клао теле у присуству две свиње и једне краве” које је Милорад навео као сведоке да није у питању препродаја туђег меса. Као солидан познавалац млекаџијског бизниса млеко је „крштавао” тј. доливао воду ради привидног већег обима производње али никад са бунара јер је та вода опасна по здравље размаженог градског живља. Ипак дочекао је природну смрт, што је данас реткост за домаћег бизнисмена. Својевремено је Милораду због исмејавања власти било одузето грађанско право да бира и да буде биран, али је он то спремно дочекао са изграђеним политичким речником: „Ја другови поздрављам ту вашу одлуку’. Своја запажања у смислу ко му од купаца колико дугује, исписивао је ситно на зиду степеништа уз огромни графит 'Нека вјечно живи име Тито” (Крстић 2000: 19).

Овај одломак оставља утисак спонтане, растерећене нарације прожете хумором, а обавештења о животу јунака делују веродостојно. Технике уверавања читалаца у поузданост казивања обухватају позицију свезнајућег приповедача (наратор преноси речи свог јунака упућене властима) и позивање на ослонце сећања (новински чланак, материјални траг на зиду зграде). Комично-подсмешљиви портрет Милорада из Пиносаве одаје, с једне стране, симпатије наратора према млекаџијином оригиналном отпору властима и спремности да прихвати последице, а с друге, дистанцу у односу на његову изразиту прагматичност и трговачке преваре. Динамичан ритам приповедања изграђује се слободним кретањем наратора по временској оси прошлости и садашњости, варирањем устаљених мотивских образаца и схема животних сценарија, поигравањем очекивањима читалаца. Милорадове 
илегалне активности и боравак у затвору делују као вид травестије биографског обрасца какав је био омиљен у соцреалистичкој литератури, алузијом на градске илегалце који су се борили против окупатора. Уз то, млекаџија је близак типу досетљивог протагонисте народних шаљивих прича и анегдота који понекад изиграва будалу како би извукао корист или како би се наругао противницима и надиграо их. Мада је потенцијални драмски сукоб између наивних грађана и превејаног сељака остао у позадини, ублажен хумором (а то је типично београдски, „ослободилачки смех”, како је у другом контексту написао Света Лукић 1995: 34), „идеолошко ја” наратора (Смит, Вотсон 2001: 61) открива аспект личног и социјалног идентитета самог аутора аутобиографије - толеранцију и прихватање других без обзира на разлике, поготово у строго надзираном послератном окружењу. Треба напоменути да је Милорад у наведеном одељку прикључен опису станара зграде у којој је аутор-наратор одрастао, а сама зграда узета је као пример „складног живота у овој вишенационалној заједници" (Крстић 2000: 19). Отуд се лик Другог ту приближава фигури суседа, блиског Другог, мада Милорад није сусед већ се његове везе са станарима изграђују управо посредством деловања механизама свакодневице, економске потребе и потрошње.

\section{Две успомене на посластичаре Горанце: наративни идентитет и другост}

Осим млекаџија, у усменим историјама и аутобиографијама као актери у свакодневним призорима на улицама Београда срећу се разни продавци и радници, међу којима су неки били из других регија и етничких средина. Ђорђе Трифуновић у сећањима из детињства (2013) помиње уличне продавце гибанице, вероватно Војвођане, затим дротаре Словаке, па продавце ситне галантерије Личане, које су купци дозивали личним именом Мане; такође и тестераше Арнауте и Роме скупљаче. Драге успомене везују га за вредне посластичаре Горанце. Трифуновић је као дете често навраћао у њихову радњу у Булевару краља Александра и уживао у незаборавним укусима и мирисима:

И врло мали сам био кад сам почео [да одлазим] и стално тамо висио и много времена тамо проводио када они праве шећерлеме, ораснице и такозване слатке грудве, ја их тако зовем, слатке грудве. Шта то значи? Они кокају кукуруз па онда неком црвеном течношћу, заслађеном и лепљивом, праве грудве [...], слатке, од тог коканог кукуруза. И то је, могу да Вам кажем, невероватно укусно. [...] Кад узмете да гризете, то се лепо онако одваја и фино се круни, и ви једете то као неку најлепшу и најмекшу јабуку. [...] Е сад, када се направе ове слатке грудве посебно су ишли, ови млађи су ишли и продавали. И онда они иду по улицама и продају те слатке црвене грудве, сећам се (Трифуновић 2013).

Евоцирање мириса и укуса из посластичарске радње премошћује сећање и учвршћује уверљивост нарације. Пошто је овај одломак издвојен из обимнијег казивања, треба рећи да је у наставку Трифуновић прилагођавао хронологију догађаја да би поменуо некадашње и активне горанске посластичарнице у Београду. Користећи се пролепсом, аутор-приповедач се освр- 
нуо на свој обичај да повремено код „Пеливана” купује ћетен-алву. Повезивањем наклоности лика дечака с афинитетима одраслог аутора-приповедача, сећања на детињство и актуелна свакодневна пракса спајају се у континуиран временски лук, чиме се учвршћује утисак да је казивање документарно. У прилог веродостојности приповедања говоре и неке просторно-географске одреднице, нпр. Трифуновић је потанко описао пут којим је стизао до радње, објашњавао где су се налазили малени станови у којима су Горанци боравили, ${ }^{3}$ описивао где је куповао слаткише на улици. Такво просторно ситуирање није само у служби стварања амбијента, већ представља облик „просторне метафоре" (Нојман 2008: 340), начин да се оцртавањем просторних референци успомене визуализују и да им се придају чвршћа структура и прегледна организација.

Колективни лик посластичара Горанаца искоришћен је и као миље другости, јер се из тог фона издваја идентитет лика дечака у односу на друге. Да би се наративно сопство конституисало, потребно је да лик буде изложен погледу других и да саобраћа с њима (Флудерник 2007: 261). Трифуновић иначе приповеда о сусретима дечака с многобројним суседима, пролазницима, продавцима, а сусрети се махом одвијају на улицама. У таквом узајамном саобраћању утврђује се наративни идентитет лика и афирмишу се његове значајне слободе, а пре свега слобода кретања дечака на улицама, слобода комуникације, слобода личности (в.: Петровић 2015). У случају Горанаца веза се продубљује, будући да је Трифуновић у истом разговору (2013) испричао епизоду о новом сусрету с њима после извесног времена:

\footnotetext{
И једанпут, два онако мало старија човека долазе и гледају онако, улазе у двориште и у нашу кућу и кажу: - Овде станује сада... И сад, питају моју мајку: - Је л' има овде неки Ђока, Ђокица? Ја кажем: - Ја сам! - А ти си! И онда они, знате, приђу, то су ти Горанци били. Замислите да сам био већ у вишим разредима гимназије, замислите колико је времена прошло. Они су запамтили и дошли су у Београд... И онда моја мајка: - А ви сте! Ајде унутра! И онда су они дошли ту, пили кафу и све, причају [...] и замислите, донели су ми плетене чарапе.
}

Стасавање дечака у гимназијалца представљено је посредством идентификације Другог. Горанци су упамтили несташног дечака („Ми знамо да има онај Ђокица који је долазио код нас, стално био са нама"), али су свесни протока времена („Слушај, претпостављамо, ми смо рачунали да си ти већ велики момак и ево...”). На тај начин, аспекти идентитета постоје управо кроз испољавање лика у комуникацији с другима, који га признају и потврђују (или оспоравају). Овај поступак објашњава Нојман: 'ја које се сећа' „конституише свој идентитет у дијалогу са својим сопством из прошлости”, што чини „процес унутар којег се диференцијални аспекти идентитета, у идеалном случају,

\footnotetext{
${ }^{3}$ О боравку у скученим просторијама великог броја сиромашних људи који су долази у Београд у потрази за послом крајем двадесетих година 20. века каже се у једном извештају следеће: „Спавају по подрумима, таванима, шупама, недовршеним и у пола срушеним грађевинама ... спавају по неколико у простору који није довољан ни за једног”, Д. Аранђеловић, Дом за печалбаре, Општинске новине 47, 1929, 15, 4, према: Чалић 2004: 372.
} 
интегришу у темпорални континуум у приповедном модусу, и испољавају се као релативно јединство" (Нојман 2008: 334).

\section{Завршна разматрања}

Неколико фрагмената из усмених историја и аутобиографија, којима су илустровани призори из свакодневног живота на улицама Београда 1930-1950, само су мали део необично занимљивих, жанровски и тематски разноврсних извора. Отуда дискусија о наративним поступцима, употреби дескрипција, облицима хронолошког и просторног представљања и исказивања наративног идентитета, далеко је од тога да буде исцрпена. Субјективни ставови, схватања и осећања имају важну улогу у вербализацији односно текстуализовању сећања, а већ сам избор одређених сећања мотивисан је потребом да се изразе и одређени аспекти властитих идентитета. На садржину и начин представљања призора из свакодневног живота у граду битно утичу и концепција приповедача-аутора, избор жанра и модуса, тип мимезе и медијације у погледу имагинације и документарности, те очекивања истраживача и слушалаца у интервјуу, односно замишљених читалаца у аутобиографској прози.

Приповедно обликовање сећања даје различите верзије слике сопства које се мењају с обзиром на време, околности, улоге, врсту перформанса. Указано је да те различите верзије опстају ако су потврђене у дијалектичком процесу интеракције идентитета и алтеритета (Флудерник 2007: 261), и отуд је различитост неопходна за освешћивање идентитета и њихово приповедно исказивање. Идентитети и сећања су јединствени, као што је јединствено њихово оживљавање кроз нарацију. Праксе свакодневног живота својим ритмом, структуром и апсорбовањем појединца утичу на организацију сећања, а разне чињенице, утисци, емоције, као и културни, фолклорни и други обрасци утичу на организацију приповедања.

\section{ЛИТЕРАТУРА}

Асман 2011: A. Asman, Duga senka prošlosti, prev. D. Gojković, Beograd: Biblioteka XX vek.

Бел, Де Шалит 2011: D. A. Bell, A. de-Shalit, The Spirit of Cities. Why Identity of a City Matters in a Global Age, Oxford: Princeton University Press.

Виландер, Ларсон 2006: J. Willander, M. Larsson. Smell Your Way Back to Childhood: Autobiographical Odor Memory, Psychonomic Bulletin \& Review $13 / 2,240-244$.

Вујовић 2014: S. Vujović, Socioprostorni identitet Beograda u kontekstu urbanog i regionalnog razvoja Srbije, Sociologija LVI/2, 145-166. 
Дорошки 1997: Н. Дорошки, Отргнуто од заборава. Сећање на људе и догађаје од 1922. до 1996. године, Београд: С. Машић.

Зебалд 2010: G. Sebald, Aspects of a Theory of Memory, in: Formen und Funktionen sozialer Gedächtnisse. Erlangen, 1-11. https://www.soziologie. phil.fau.de/team/sebald/

Кресвел 2004: T. Cresswell, Place: A Short Introduction, Malden, MA: Blackwell Pub.

Крстић 2000: М. Крстић, Аутобиографија, Београд: Аутор.

Лакчевић 2011: Ксенија Лакчевић, Теренска збирка (настала у оквиру предмета Теренско истраживање фолклора), садржи видео-снимак и транскрипт разговора с Михаилом Лакчевићем од 20. 1. 2011. у Београду. Дигитални архив Филолошког факултета, Београд.

Лукић ${ }^{2} 1995:$ С. Лукић, Бивши Београд, Београд: Издавачка агенција „Драганић”.

Нининг 2007: A. Nünning, Towards a Typology, Poetics and History of Description in Fiction, in: W. Wolf, W. Bernhart (ed.), Description in Literature and Other Media, Amsterdam, New York: Rodopi.

Нојман 2008: B. Neumann, The Literary Representation of Memory, in: A. Erll, A. Nünning (ed.), Cultural Memory Studies. An International and Interdisciplinary Handbook, Berlin, New York: Walter de Gruyter, 333-343.

Оринг 1988: E. Oring, Generating Lives: The Construction of Autobiography, in: T. Hofer, P. Niedermüller (ed.), Life History as Cultural Construction/Performance, Budapest: The Ethnographic Institute of the Hungarian Academy of Sciences, 179-211.

Петровић 2015: С. Петровић, И град и варош: сећања на свакодневни живот у предратном Београду, Гласник Етнографског института САНУ 63/1, $85-99$.

Поповић 1964: Д. Ј. Поповић, Београд кроз векове, Београд: Туристичка штампа.

Пушић 22015: Lj. Pušić, Grad, društvo, prostor: sociologija grada, Beograd: Zavod za udžbenike.

Радовановић 1974: М. В. Радовановић, Демографски односи 1918-1941. године, y: В. Чубриловић (ур.), Историја Београда 3, Београд: Просвета, 157-162.

Радовић 2013: S. Radović, Grad kao tekst, Beograd: Biblioteka XX vek.

Рајан 2009: Ryan, M.-L. Space, in: P. Hühn et al. (ed.) Handbook of Narratology, Berlin, New York: Walter de Gruyter, 420-433.

Серто 1988: M. de Certeau, The Practice of Everyday Life. Translated by S. Rendall. Berkeley, Los Angeles, London: University of California Press.

Смит, Вотсон 2001: S. Smith, J. Watson, Reading Autobiography: A Guide for Interpreting Life Narratives, Minneapolis, London: University of Minnesota Press.

Спасић 2004: I. Spasić, Sociologije svakodnevnog života, Beograd: Zavod za izdavanje udžbenika.

Спасић, Бацковић 2017: I. Spasić, V. Backović, Gradovi u potrazi za identitetom, Beograd: Univerzitet u Beogradu - Filozofski fakultet, Institut za sociološka istraživanja. 
Трифуновић 2013: Аудио-снимак разговора са Ђорђем Трифуновићем од 20. 2. 2013, разговор снимила Соња Петровић, лични архив.

Флудерник 2007: M. Fludernik, Identity/alterity, in: D. Herman (ed.), The Cambridge Companion to Narrative, Cambridge: Cambridge University Press, 260-273.

Хајмор 2006: B. Highmore, Michel de Certeau Analysing Culture, London, New York: Continuum.

Херман 2002: D. Herman, Story Logic: Problems and Possibilities of Narrative, Lincoln: University of Nebraska Press.

Чалић 2004: М.-Ж. Чалић, Сочијална историја Србије 1815-1941, Београд: Clio.

Шаринић, Чалдаровић 2015: J. Šarinić, O. Čaldarović, Suvremena sociologija grada, Zagreb: Naklada Jesenski i Turk, Hrvatsko sociološko društvo.

Sonja D. Petrović

EVERYDAY LIFE IN THE STREETS OF BELGRADE: CONSTRUCTION OF AUTOBIOGRAPHICAL MEMORIES IN ORAL HISTORY AND AUTOBIOGRAPHY

\section{(Summary)}

Procedures of narrative representation and construction of autobiographical memories of the everyday life in Belgrade c. 1930-1950 are discussed and illustrated with excerpts of the selected oral histories and autobiographies. Various research of autobiographical and cultural memory, Michel de Certeau's writings on everyday life, narratological studies of narrative identity, symbolic/cultural geography literature on the concepts of space and place, and sociological studies about symbolic and discursive approaches to contemporary cities, served as a theoretical base for this article.

Acknowledging that the city public spaces are the places where live social contacts and exchanges are taking place, and that they at the same time represent spaces of learning about the difference and alterity, the elements of the city space become the means of identification in narrative construction of memories. In that context, the paper discusses procedures of narrative articulation of autobiographical memories about Belgrade street vendors 1930-1950. As a form of creating of social reality and a way of presentation of self in relation to alterity and difference, memories are fragmentary and amorphous. In the process of narrative construction, the memories gain structure and stability, but they also change, adapt and reconstruct. The act of reviving the spirit of the city in memories presents dynamical identity process, supported and enables by social structures, rituals and everyday practice. Therefore, the aspects of identity manifest through approving an individual (or a narrative existent) in communication with the others, who recognize and affirm or contest him. 